\title{
DFT Study of the Silyl Esters of Thiophosphorus Acids
}

\author{
Marek Cypryk • Grzegorz Krasiński
}

Received: 14 September 2010 / Accepted: 10 January 2011 / Published online: 12 February 2011

(C) The Author(s) 2011. This article is published with open access at Springerlink.com

\begin{abstract}
Quantum mechanical DFT calculations of the model methyl and silyl esters of simple thiophosphorus acids are presented which help to predict some structural features and reactivity aspects of these reactants. Their applicability in organophosphorus chemistry is discussed.
\end{abstract}

Keywords Silyl esters of thiophosphoric acids $\cdot$ Silyl esters of thiophosphinic acids $\cdot$ Structure $\cdot$ Reactivity $\cdot$ DFT calculations

\section{Introduction}

Phosphorus acids and their esters play an essential role in the chemistry of life. Among them, thiophosphorus acids are of particular importance in organophosphorus chemistry. A change in the rate of hydrolysis has been observed to accompany this sulfur substitution, leading to a phenomenon known as the "thio effect" [1]. The simple replacement of an anionic oxygen by sulfur in the phosphate group (PO-oligonucleotides) not only enhances the resistance to degradation by nucleases [2] but also, in many instances, favorably alters the biological activity [3, 4]. Several phosphorothioate antisense oligonucleotides (PS-ODNs)

This communication is dedicated to Prof. Yitzhak Apeloig on the occasion of receiving 2010 Kipping Award in recognition of his outstanding contribution to silicon chemistry

M. Cypryk $(\bowtie) \cdot$ G. Krasiński

Center of Molecular and Macromolecular Studies, Polish

Academy of Sciences,

Sienkiewicza 112,

90-363 Łódź, Poland

e-mail: mcypryk@cbmm.lodz.pl constitute a new class of potent drugs directed against various diseases and are currently undergoing clinical evaluation for a number of diseases, including cancer, viral infections, and inflammatory disorders [5-8]. The thionothiolo isomerization of O-alkyl esters of thiophosphoric acids to corresponding S-alkyl isomers is one of the most important reactions because of high biological activity of both esters. The isomerization can be effected by both bases (amines, phosphines) and acids [9, 10].

Recent decades have witnessed a dynamic growth in the area of silicon-containing organophosphorus reagents. Their potential in the synthesis of organophosphorus compounds of industrial, biological, medical, and other synthetic uses have been widely recognized and exploited $[11,12]$.

The silyl ester function plays an important role in organic chemistry especially as a versatile protecting group in multistep synthesis [13]. Phosphorus esters undergo facile transesterification reactions with silyl halides to form the corresponding phosphorus silyl esters and alkyl halides $[14,15]$. The silyl esters are cleaved by protic solvents under very mild conditions to yield the phosphorus acids which are often hardly available by any other route [12]. An important application of silyl esters of tetracoordinate phosphorus is connected with their use as precursors of phosphorus acids applied as models for biochemical mechanistic studies [16-21].

Theoretical studies of small phosphate and thiophosphate models is an important step toward a detailed understanding of many biochemical processes at the atomic level [22-26]. We present here theoretical predictions of some structural features and reactivity aspects, in particular, thiono-thiolo isomerization of model silyl esters of oxyand thio-phosphorus acids, that have never received even a cursory theoretical explication. 


\section{Experimental}

\subsection{Gas-Phase Calculations}

All the structures were optimized in the gas phase with Kohn-Sham density functional theory (DFT) methods using the hybrid exchange functional of Becke [27] and the Lee, Yang, and Parr correlation functional [28] (B3LYP). Geometry optimizations were done in redundant internal coordinates with default convergence criteria [29]. Frequency calculations were performed to establish the nature of all stationary points and to allow evaluation of thermodynamic quantities such as thermal vibrational contributions to the enthalpy, entropy and Gibbs free energy.

The geometry optimization and frequency calculations were performed using the $6-31+\mathrm{G}(\mathrm{d})$ basis set. Electronic energies were obtained via single-point calculations at the optimized geometries using the $6-311+\mathrm{G}(2 \mathrm{~d}, \mathrm{p})$ basis set and the B3LYP hybrid density functional. This protocol for obtaining the geometry and energy is designated by the abbreviated notation B3LYP/6-311+G(2d,p)//B3LYP/6-31+G(d). Single-point calculations were run with "tight" convergence criteria [30] to ensure high precision for properties sensitive to the use of diffuse basis functions. This method typically yields relative energies within $3 \mathrm{kcal} / \mathrm{mol}$ of experimental values [31]. Because of known limitations of density functional theory, the high level CCSD/6-311+G(2d,p)//B3LYP/6-31+G(d) method was also used to determine single-point energies for the simple structures, to verify the reliability of the DFT results for the class of compounds studied [32]. All electronic structure calculations were performed with the Gaussian 03 suite of programs [30].

\subsection{Analysis of Softness and Nucleophilicity}

Softness and local nucleophilicities of oxygen and sulfur centers were analyzed in terms of the condensed Fukui functions, $\mathrm{f}_{\mathrm{k}}^{-}=\mathrm{q}_{\mathrm{k}}(\mathrm{N})-\mathrm{q}_{\mathrm{k}}(\mathrm{N}-1)$ and $\mathrm{f}_{\mathrm{k}}^{+}=\mathrm{q}_{\mathrm{k}}(\mathrm{N}+1)-$ $q_{k}(N)$ [33]. For a system of $N$ electrons, independent calculations were made for the corresponding $(\mathrm{N}-1)-, \mathrm{N}-$ and $(\mathrm{N}+1)$-electron systems using molecular geometry optimized for N-electron species. Natural electron populations $q_{k}(N)$ required for calculation of the Fukui functions were computed using the NBO theory as implemented in Gaussian 03 at the B3LYP/6-31+G* level [34]. Global softness was calculated as $\sigma=1 /(\mathrm{IP}-\mathrm{EA})$, where IP is the vertical ionization potential and EA is the vertical electron affinity of the

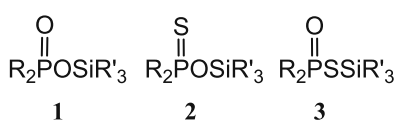

Fig. 1 Structures of the model compounds, where $\mathrm{R}=\mathrm{H}, \mathrm{Me}, \mathrm{F}, \mathrm{OMe}$ and $\mathrm{NH}_{2} ; \mathrm{R}^{\prime}=\mathrm{H}$ and $\mathrm{Me}$
Table 1 B3LYP/6-31+G(d) bond lengths $(\AA)$ in silyl esters of thiophosphorus acids $\mathrm{R}_{2} \mathrm{P}(\mathrm{X}) \mathrm{YSiH}_{3}, \mathrm{X}, \mathrm{Y}=\mathrm{O}, \mathrm{S}$

\begin{tabular}{lllllll}
\hline $\mathrm{R}$ & $\mathrm{P}=\mathrm{O}$ & $\mathrm{P}-\mathrm{S}(\mathrm{Si})$ & $\mathrm{S}-\mathrm{Si}$ & $\mathrm{P}=\mathrm{S}$ & $\mathrm{P}-\mathrm{O}(\mathrm{Si})$ & $\mathrm{O}-\mathrm{Si}$ \\
\hline $\mathrm{H}$ & 1.497 & 2.120 & 2.185 & 1.946 & 1.623 & 1.696 \\
$\mathrm{Me}$ & 1.504 & 2.144 & 2.181 & 1.961 & 1.637 & 1.693 \\
$\mathrm{~F}$ & 1.473 & 2.071 & 2.205 & 1.911 & 1.580 & 1.711 \\
$\mathrm{OMe}$ & 1.491 & 2.100 & 2.186 & 1.946 & 1.601 & 1.696 \\
$\mathrm{NH}_{2}$ & 1.496 & 2.133 & 2.181 & 1.960 & 1.628 & 1.695 \\
\hline
\end{tabular}

electrophile/nucleophile. Local softness of atom $\mathrm{k}$ was defined as $s_{k}=\sigma f_{k}[33]$.

\subsection{Solvation Calculations}

Solvation effects were treated by single point calculations based on the gas-phase optimized structures using the CPCM polarizable conductor calculation model [35] as implemented in Gaussian 03, using atomic radii optimized for the PBE1PBE/6-31G(d) level of theory (UAKS). In the present work the approximation is made that the gas-phase geometry, entropy, and thermal corrections to the enthalpy do not change upon solvation.

\section{Results and Discussion}

\subsection{Geometries of Model Compounds}

As model compounds for this preliminary study we have chosen simple $\mathrm{P}(\mathrm{IV})$ phosphorus and thiophosphorus acids and their silyl esters of general formulas (Fig. 1).

We have also calculated the geometries and energies of the corresponding acids and methyl esters. The selected bonding parameters of these model compounds are collected in Table 1.

Calculated bond lengths of phosphorus to oxygen and sulfur agree well with typical values measured by crystallographic methods [36]. Bonding parameters for F- and Me-substituted esters differ considerably from those of the other analogues. When $\mathrm{R}=\mathrm{F}$ the adjacent $\mathrm{P}=\mathrm{X}$ and $\mathrm{P} \mathrm{Y}(\mathrm{Si})$ bonds to phosphorus are significantly shorter than for the other derivatives. For $\mathrm{R}=\mathrm{Me}$ the opposite trend is observed. This points to the importance of the inductive effect of the substituents at phosphorus. Surprisingly, the bond lengths for $\mathrm{R}=\mathrm{OMe}$ and $\mathrm{NH}_{2}$ are not different from those in the case of $\mathrm{R}=\mathrm{H}$. This suggests that for these

$$
\stackrel{\text { II }}{\mathrm{R}_{2} \mathrm{POR}^{\prime}} \rightleftharpoons \stackrel{\mathrm{O}}{\mathrm{I}} \underset{\mathrm{R}_{2} \mathrm{PSR}^{\prime}}{ }
$$

Scheme 1 Thiono-thiolo rearrangement of thiophosphorus esters 
esters the inductive and back-donating (anomeric) effects, which operate in opposite directions, compensate each other. The importance of the anomeric effect in the chemistry of phosphorus esters is well recognized [37]. Wiberg bond orders for ' $\mathrm{P}=\mathrm{O}$ ' and ' $\mathrm{P}=\mathrm{S}$ ' terminal bonds are in all cases in the range of $1.2-1.35$ and $1.48-1.65$, respectively. This supports the observation made previously that neither bond is a true double bond but they show rather an intermediate character [38]. Upon exchange of methyls by fluorines at phosphorus the Wiberg bond order of terminal ' $\mathrm{P}=\mathrm{O}$ ' bond increases from 1.22 to 1.34 in silyl phosphorothiolate and the bond order of terminal ' $\mathrm{P}=\mathrm{S}$ ' bond increases from 1.48 to 1.65 in silyl phosphorothionate. This change confirms that the inductive effect of fluorine enhances the double bond character of these terminal bonds. Detailed analysis of the structural features of these silyl esters will be reported elsewhere.

\subsection{Thermodynamics}

The $\mathrm{P}-\mathrm{S}-\mathrm{Si}$ bond sequence is much weaker than $\mathrm{P}-\mathrm{O}-\mathrm{Si}$. The average overall energy of this system is $122 \mathrm{kcal} / \mathrm{mol}$ $(512 \mathrm{~kJ} / \mathrm{mol})$ compared to $194 \mathrm{kcal} / \mathrm{mol}(813 \mathrm{~kJ} / \mathrm{mol})$. The energy difference between $\mathrm{P}=\mathrm{O}$ and $\mathrm{P}=\mathrm{S}$ double bonds is $57 \mathrm{kcal} / \mathrm{mol}(240 \mathrm{~kJ} / \mathrm{mol})$. Thus, the energy difference between thiono- and thiolo-silyl esters is about $14 \mathrm{kcal} / \mathrm{mol}$ $(60 \mathrm{~kJ} / \mathrm{mol})$ in favor of thiono form [39]. This thermodynamics explains why thiolo-silyl esters are so difficult to prepare. The chemistry of derivatives of tetracoordinated phosphorus thioacids containing trimethylsilyl groups attached to phosphorus via a sulfur bridge have recently been developed giving rise to interesting intermediates for the synthesis of useful organothiophosphorus derivatives [40-43].

We have computed the energetics of simple thiono-thiolo isomerization of model esters (Scheme 1). The results are presented in Table 2 .

Table 2 B3LYP/6-311+G(2d,p)//B3LYP/6-31+G(d) Gibbs free energies $\Delta \mathrm{G}(\mathrm{kcal} / \mathrm{mol})$ for thiono-thiolo rearrangement of model thiophosphorus esters (Scheme 1)

\begin{tabular}{lllll}
\hline $\mathrm{R}$ & $\begin{array}{l}\mathrm{R}^{\prime}=\mathrm{H}^{\mathrm{a}} \\
(\mathrm{MeCN})\end{array}$ & $\begin{array}{l}\mathrm{R}^{\prime}=\mathrm{CH}_{3}{ }^{\mathrm{a}} \\
(\mathrm{MeCN})\end{array}$ & $\begin{array}{l}\mathrm{R}^{\prime}=\mathrm{SiH}_{3}{ }^{\mathrm{a}} \\
(\mathrm{MeCN})\end{array}$ & $\begin{array}{l}\mathrm{R}^{\prime}=\mathrm{SiMe}_{3} \\
(\mathrm{MeCN})\end{array}$ \\
\hline $\mathrm{H}$ & $4.7(4.0)$ & $-4.7(-6.1)$ & $12.3(10.9)$ & $14.4(13.4)$ \\
& $3.9(4.4)$ & $-5.0(-6.9)$ & $13.6(12.2)$ & \\
$\mathrm{Me}$ & $4.6(3.5)$ & $-6.3(-6.9)$ & $11.1(10.2)$ & $13.1(12.6)$ \\
& $4.3(4.5)$ & $-6.0(-7.5)$ & $13.0(12.0)$ & \\
$\mathrm{F}$ & $1.8(2.4)$ & $-7.1(-8.1)$ & $10.0(9.4)$ & $11.9(11.4)$ \\
& $0.9(4.1)$ & $-7.4(-8.5)$ & $11.1(9.7)$ & \\
$\mathrm{OMe}$ & $1.4(1.4)$ & $-7.1(-7.9)$ & $9.7(9.0)$ & $12.0(11.6)$ \\
& & $-7.3(-8.4)$ & & \\
$\mathrm{NH}_{2}$ & $1.9(1.1)$ & $-7.1(-8.2)$ & $9.3(8.3)$ & $11.4(11.0)$ \\
\hline
\end{tabular}

${ }^{\mathrm{a}}$ In italics are given the CCSD/6-311+G(2d,p)//B3LYP/6-31+G(d) values

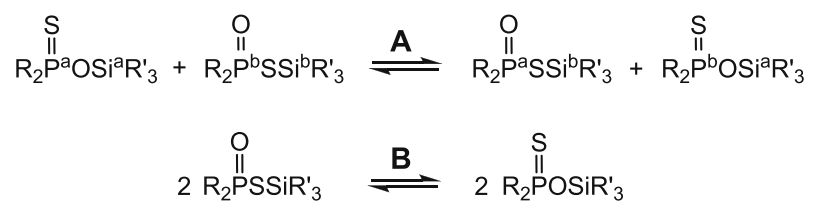

Scheme 2 Intermolecular thiono-thiolo isomerizations of silyl esters of thiophosphorus acid

The reliability of DFT results was supported by the CCSD calculations for small model species. The results obtained by both methods are in very good agreement with each other (Table 2). Calculations confirmed the experimental results that alkyl esters are more stable in the thiolo form. This is the driving force of the Pishchimuka reaction of thiono esters with alkyl halides. Acids preferentially exist in thiono form as it was observed earlier [38] although the energy difference between two forms is not large and decreases when electron-withdrawing substituents are attached to phosphorus. In contrast to alkyl esters, silyl derivatives are more stable in thiono form by $9-12 \mathrm{kcal} / \mathrm{mol}$ $\left(\mathrm{SiH}_{3}\right)$; in the case of $\mathrm{R}^{\prime}=\mathrm{SiMe}_{3}$ the relative energy difference is by $2 \mathrm{kcal} / \mathrm{mol}$ larger, in accord with earlier estimations [39].

\subsection{Reactivity}

Silyl esters of phosphorus show interesting reactivity. Nucleophilic attack on the silicon atom is strongly preferred over the attack on phosphorus. The presence of a silyl group seems to enhance nucleophilicity of the phosphoryl group, and the phosphoryl group increases the electrophilicity of the silicon center. Thus, many reactions of silyl esters of phosphorus are much faster than those of corresponding alkyl esters [13]. One of the important problems in their chemistry is the isomerization and exchange of silyl groups. These processes lead to inversion of configuration and racemization at both silicon and phosphorus centers. Exchange reactions may be catalyzed by silyl halides [44] or by another molecule of the ester [45].

We have calculated the energy barriers of intra- and intermolecular exchange of silyl groups in esters of phosphorus acids (Schemes 2) to compare the feasibility of these reactions. Both reactions have different stereochemical consequences. Intramolecular exchange results in thiono-thiolo isomerization but the configuration at $\mathrm{Si}$ and $\mathrm{P}$ is preserved (Scheme 1, Fig. 2). Intermolecular process can occur with a 'symmetrical' arrangement of phosphorus moieties (Scheme 2, Fig. 3, path A) or with an 'asymmet-

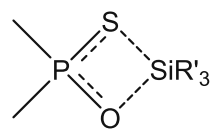

Fig. 2 Intramolecular silyl group migration in thiophosphorus esters 


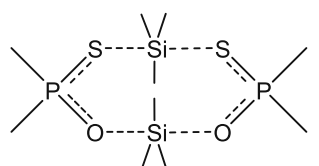

A

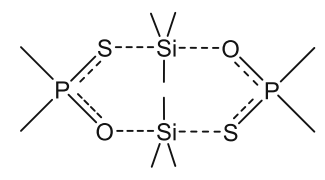

B
Fig. 3 Transition states in intermolecular thiono-thiolo symmetrical (a) and asymmetrical (b) isomerizations of silyl esters of thiophosphorus acids

rical' arrangement (Scheme 2, Fig. 3, path B). Exchange according to path $\mathbf{A}$ results in inversion of configuration at $\mathrm{Si}$ and racemization if chiral silyl substituents are used. The configuration at $\mathrm{P}$ does not change unless two differently substituted esters are allowed to react. Path $\mathbf{B}$ results in configuration inversion at $\mathrm{Si}$ and in thiono-thiolo isomerization in both ester molecules. The calculation results for both processes are collected in Tables 3 and 4 .

To verify the reliability of DFT results the calculations for small model species were performed also with the CCSD method using B3LYP/6-31+G(d) geometries. In the case of reaction barriers, the DFT results are systematically lower than those obtained by the coupled cluster method by ca. $3.5 \mathrm{kcal} / \mathrm{mol}$ and ca. $7.5 \mathrm{kcal} / \mathrm{mol}$ for $\mathrm{R}^{\prime}=\mathrm{H}$ and $\mathrm{R}^{\prime}=$ Me, respectively, but only by $1-2 \mathrm{kcal} / \mathrm{mol}$ for $\mathrm{R}^{\prime}=\mathrm{SiH}_{3}$ (Table 3). The energy barriers for thiono-thiolo isomerization for each class of compounds are very similar, little dependent of the substituents at phosphorus. Methyl esters show the highest energy barriers, over $50 \mathrm{kcal} / \mathrm{mol}$, which seem to prevent the reaction of this type from occurring under normal conditions. Silyl $\left(\mathrm{SiH}_{3}\right)$ esters show barriers even lower than the corresponding acids which suggests that the intramolecular migration of the silyl group is feasible, at least at elevated temperatures. The trimethylsilyl group is accompanied with an increase of the reaction barrier by $5-6 \mathrm{kcal} / \mathrm{mol}$ compared to $\mathrm{SiH}_{3}$, due to steric reasons. Solvent has little effect on the isomerization barrier.

The barriers for intermolecular silyl group exchange are higher than those for intramolecular migration for all $\mathrm{R}$ except $\mathrm{R}=\mathrm{H}$. The calculated barriers of the reaction $\mathbf{A}$ are slightly lower (by about $3 \mathrm{kcal} / \mathrm{mol}$ ) than those of the reaction $\mathbf{B}$ for all $\mathrm{R}$ except $\mathrm{R}=\mathrm{F}$, where the energy barriers for both reactions are identical. We have not performed coupled cluster calculations because of the computational cost. Based on the differences between two methods shown in Table 3, those barriers are predicted to be about $8 \mathrm{kcal} /$ mol higher than the DFT barriers.

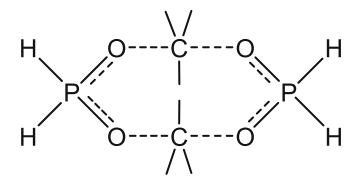

Fig. 4 Exchange of methyl groups in methyl phosphinate $\mathrm{H}_{2} \mathrm{P}(\mathrm{O})$ $\mathrm{OMe}$
Table 3 B3LYP/6-311+G(2d,p)//B3LYP/6-31+G(d) Gibbs free energy barriers $\Delta \mathrm{G}^{ \pm}(\mathrm{kcal} / \mathrm{mol})$ for intramolecular thiono-thiolo rearrangement of model phosphorus esters, $\mathrm{R}_{2} \mathrm{P}(\mathrm{S}) \mathrm{OR}$ ' (Scheme 1, Fig. 2) in the gas phase and in $\mathrm{MeCN}$ (values in parentheses)

\begin{tabular}{lllll}
\hline $\mathrm{R}$ & $\mathrm{R}^{\prime}=\mathrm{H}^{\mathrm{a}}$ & $\mathrm{R}^{\prime}=\mathrm{CH}_{3}{ }^{\mathrm{a}}$ & $\mathrm{R}^{\prime}=\mathrm{SiH}_{3}{ }^{\mathrm{a}}$ & $\mathrm{R}^{\prime}=\mathrm{SiMe}_{3}$ \\
\hline $\mathrm{H}$ & $30.0(30.5)$ & $50.6(50.4)$ & $24.9(24.5)$ & $31.8(31.5)$ \\
& $33.7(36.6)$ & $58.0(57.7)$ & $26.0(26.7)$ & \\
$\mathrm{Me}$ & $28.1(28.7)$ & $50.8(51.2)$ & $22.7(22.9)$ & $30.1(30.6)$ \\
& $31.5(31.3)$ & $59.0(58.8)$ & $24.5(23.8)$ & \\
$\mathrm{F}$ & $31.9(33.5)$ & $50.4(48.7)$ & $27.0(27.7)$ & $32.4(33.0)$ \\
& $35.5(39.2)$ & $58.3(57.7)$ & $28.7(29.5)$ & \\
$\mathrm{OMe}$ & & 53.5 & $24.2(23.9)$ & \\
& & 60.9 & & \\
$\mathrm{NH}_{2}$ & $26.0(26.5)$ & $52.8(52.6)$ & $21.7(20.7)$ & \\
\hline
\end{tabular}

${ }^{\mathrm{a}}$ In italics are given the $\mathrm{CCSD} / 6-311+\mathrm{G}(2 \mathrm{~d}, \mathrm{p}) / / \mathrm{B} 3 \mathrm{LYP} / 6-31+\mathrm{G}(\mathrm{d})$ values

To compare the energy barriers for the intermolecular exchange of silyl groups with the analogous reaction of methyl esters, the Gibbs free energy barrier for the exchange of methyl groups between two molecules of methyl phosphinate $\mathrm{H}_{2} \mathrm{P}(\mathrm{O}) \mathrm{OMe}$ (Fig. 4) was calculated to be $73 \mathrm{kcal} / \mathrm{mol}$ in the gas phase ( $76 \mathrm{kcal} / \mathrm{mol}$ in acetonitrile). Thus, the intermolecular exchange of silyl groups is much more likely than the analogous reaction of alkyl esters.

Solvent effects in all these reactions calculated assuming the polarizable continuum model in acetonitrile are small or negligible. This does not exclude the possibility of specific dipole-dipole interactions as the reactions in question are associated with some charge separation. Moreover, the processes discussed here are not the only ones which may be responsible for the exchange reactions of silyl esters in the condensed phase. The rearrangement may be induced by traces of basic or acidic impurities in the medium. Very effective may be the silyl group exchange catalyzed by residual acid or acid anions which are likely to be present in the mixture since silyl esters of phosphorus are very sensitive to hydrolysis. A theoretical study of these reactions is in progress.

To get deeper insight into the nucleophilicity of sulfur and oxygen in thiophosphinic acids/esters/anions the

Table 4 B3LYP/6-311+G(2d,p)//B3LYP/6-31+G(d) Gibbs free energy barriers $\Delta \mathrm{G}^{*}(\mathrm{kcal} / \mathrm{mol})$ for intermolecular silyl group exchange in model phosphorus esters (Scheme 2, Fig. 3), in the gas phase and in $\mathrm{MeCN}$ (in parentheses)

\begin{tabular}{lll}
\hline $\mathrm{R}$ & $\begin{array}{l}\mathrm{R}^{\prime}=\mathrm{SiH}_{3} \\
(\mathbf{A})\end{array}$ & $\begin{array}{l}\mathrm{R}^{\prime}=\mathrm{SiH}_{3} \\
(\mathbf{B})\end{array}$ \\
\hline $\mathrm{H}$ & $11.8(15.4)$ & $14.8(18.3)$ \\
$\mathrm{Me}$ & $37.8(39.2)$ & $41.2(42.5)$ \\
$\mathrm{F}$ & $39.2(40.5)$ & $39.4(40.8)$ \\
\hline
\end{tabular}


Table 5 Local and global softness of model nucleophiles and electrophiles

\begin{tabular}{|c|c|c|c|c|c|c|c|}
\hline \multirow[t]{3}{*}{ Compound } & \multirow{3}{*}{$\begin{array}{l}\mathrm{f}_{\mathrm{k}}^{+} \\
\mathrm{k}=\mathrm{C}, \mathrm{Si}\end{array}$} & \multirow[t]{3}{*}{$\mathrm{f}_{\mathrm{s}}^{-}$} & \multirow[t]{3}{*}{$\mathrm{f}_{\mathrm{o}}^{-}$} & \multicolumn{3}{|c|}{ Local softness, $\mathrm{s}_{\mathrm{k}}$} & \multirow[t]{3}{*}{ Global softness, $\sigma$} \\
\hline & & & & \multirow{2}{*}{$\frac{\text { Electrophile }}{\mathrm{k}=\mathrm{C} / \mathrm{Si}}$} & \multicolumn{2}{|c|}{ Nucleophile } & \\
\hline & & & & & S & $\mathrm{O}$ & \\
\hline $\mathrm{CH}_{3}^{+}$ & 0.798 & & & 1.379 & & & 1.728 \\
\hline $\mathrm{SiH}_{3}^{+}$ & 0.908 & & & 1.914 & & & 2.108 \\
\hline $\mathrm{H}_{2} \mathrm{PSO}^{-}$ & & 0.756 & 0.106 & & 2.414 & 0.338 & 3.193 \\
\hline $\mathrm{Me}_{2} \mathrm{PSO}^{-}$ & & 0.719 & 0.202 & & 2.138 & 0.599 & 2.973 \\
\hline $\mathrm{F}_{2} \mathrm{PSO}^{-}$ & & 0.742 & 0.089 & & 2.743 & 0.331 & 3.697 \\
\hline
\end{tabular}

analysis based on the condensed Fukui functions was performed. Fukui functions, $\mathrm{f}_{\mathrm{k}}^{-}$and $\mathrm{f}_{\mathrm{k}}^{+}$, are the rough measures of the nucleophilicity and electrophilicity power of atom $\mathrm{k}$, respectively [33]. Thiophosphinate anions, $\mathrm{R}_{2} \mathrm{PSO}^{-}, \mathrm{R}=\mathrm{H}, \mathrm{Me}, \mathrm{F}$, were taken as the model nucleophiles while $\mathrm{CH}_{3}{ }^{+}$and $\mathrm{SiH}_{3}{ }^{+}$were taken as model electrophiles. The values of global and local softness for all atoms of interest $(\mathrm{C}, \mathrm{Si}, \mathrm{O}$ and $\mathrm{S})$ are collected in Table 5.

The results of softness and nucleophilicity analysis support the intuitive feature that sulfur is softer and more nucleophilic than oxygen. However, the present analysis fails to explain why, in the case of silyl cation, the initial attack of the $\mathrm{O}$ atom is favorable although the softness difference is smaller for the $\mathrm{S}$ atom. Moreover, the global softness of thiophosphinate anions with regard of substituents $\mathrm{R}$ increases in order $\mathrm{Me}<\mathrm{H}<\mathrm{F}$, which is intuitively difficult to explain. These weaknesses of the present analysis demonstrate limitations of this simplified approach. It is possible that, in some extreme cases, some other stronger interaction can overwhelm the predictions made from softness alone. Here, the strong 'oxyphilicity' of silicon appears to be the dominating factor.

The calculations showed that in contrast to alkyl esters, which are more stable in the thiolo form, silyl esters of thiophosphorus acids appear in the thiono form which is thermodynamically preferred. The Gibbs free energy barriers of intramolecular migration of the ligand between oxygen and sulfur in thiophosphinates and in thiophosphinic acids increase in order $\mathrm{SiH}_{3}<\mathrm{H} \approx \mathrm{SiMe}_{3}<<\mathrm{Me}$. Energy barriers for the intermolecular exchange of ligands are significantly higher compared to intramolecular process and $\mathrm{SiH}_{3}<<$ Me. Thus intramolecular isomerization is more likely than the intermolecular process in the absence of basic or acidic impurities. The energy barriers for the discussed reaction are little dependent on the substituents at phosphorus and on solvation.

Acknowledgements This communication is dedicated to Prof. Yitzhak Apeloig on the occasion of receiving 2010 Kipping Award in recognition of his outstanding contribution to the field of silicon chemistry.
Open Access This article is distributed under the terms of the Creative Commons Attribution Noncommercial License which permits any noncommercial use, distribution, and reproduction in any medium, provided the original author(s) and source are credited.

\section{References}

1. Stivers JT, Nagarajan R (2006) Probing enzyme phosphoester interactions by combining mutagenesis and chemical modification of phosphate ester oxygens. Chem Rev 106:3443-3467

2. Cummins LL, Owens SR, Risen LM, Lesnik EA, Freier SM, McGee D, Guinosso CJ (1995) Characterization of fully 2 '-modified oligoribonucleotide hetero- and homoduplex hybridization and nuclease sensitivity. Nucleic Acids Res 23:2019-2024

3. Stein CA, Cheng YC (1993) Antisense oligonucleotides as therapeutic agents - is the bullet really magical? Science 261:1004-1012

4. Uhlmann E, Peyman A (1990) Antisense oligonucleotides: a new therapeutic principle. Chem Rev 90:543-584

5. Crooke ST (2001) In: Geary RS, Yu RZ, Leeds JM et al (eds) Pharmacokinetic properties in animals. Antisense Drug Technology. CRC, Boca Raton, pp 139-141

6. Jansen B, Zangemeister-Wittke U (2002) Antisense therapy for cancer-the time of truth. Lancet Oncol 3:672-683

7. Marcucci G, Stock W, Klisovic DG, RB LS, Klisovic MI, Blum W, Kefauver C, Sher DA, Green M et al (2005) Phase I study of oblimersen sodium, an antisense to Bcl-2, in untreated older patients with acute myeloid leukemia: pharmacokinetics, pharmacodynamics, and clinical activity. J Clin Oncol 23:3404-3411

8. Stec WJ, Cierniewski CS, Okruszek A, Kobylańska A, Pawłowska Z, Koziołkiewicz M, Pluskota E, Maciaszek A, Rębowska B, Stasiak M (1997) Stereodependent inhibition of plasminogen activator inhibitor Type 1 by phosphorothioate oligonucleotides: proof of sequence specificity in cell culture and in vivo rat experiments. Antisense Nucleic Acid Drug Dev 7:567-573

9. Stec WJ, Uznanski B, Bruzik K, Michalski J (1976) Protic acid catalyzed thiono-thiolo rearrangements of phosphorus esters. J Org Chem 41:1291-1293

10. Reimschüssel W, Adamus J (1990) Mechanism of thiono-thiolo isomerization of thiophosphates. Kinetic evidence for Hilgetag's Hypothesis. Phosphorus Sulfur Silicon 49:77-80

11. Borisov SA, Voronkov MG, Lukevits EJ (1971) Organosilicon derivatives of Phosphorus and Sulfur. Plenum, New York

12. Engel RE (1992) Handbook of organophosphorus chemistry. Marcel Dekker, New York

13. Woźniak L, Chojnowski J (1989) Silyl esters of phosphorus: common intermediates in synthesis. Tetrahedron 45:2465-2524

14. McKenna CE, Higa MT, Cheung NH, McKenna MC (1977) The facile dealkylation of phosphonic acid dialkyl esters by bromotrimethylsilane. Tetrahedron Lett 18:155-158 
15. Borecka B, Chojnowski J, Cypryk M, Michalski J, Zielińska J (1979) Synthetic and mechanistic aspects of the reaction of trialkylsilyl halides with thio- and selsno esters of phosphorus. J Organomet Chem 171:17-34

16. Hata T, Sekine M (1974) Silyl phosphites. I. Reaction of silyl phosphites with diphenyl disulfide. Synthesis of S-phenyl nucleoside phosphorothioates. J Am Chem Soc 96:7363-7364

17. Loewus DI, Eckstein F (1983) Symmetrical monothiopyrophosphate. J Am Chem Soc 105:3287-3292

18. Timperley C, Bird M, Holden I, Black RM (2001) Organophosphorus chemistry. Part 1 . The synthesis of alkyl methylphosphonic acids. J Chem Soc, Perkin Trans 126-130

19. Stawinski J, Kraszewski A (2002) How to get the most out of two Phosphorus Chemistries. Studies on H-Phosphonates. Acc Chem Res 35:952-960

20. Swierczek K, Peters JW, Hengge AC (2003) A convenient synthesis of phosphonothioic acids. Tetrahedron 59:595-599

21. Olszewski TK, Boduszek B, Sobek S, Kozlowski H (2006) Synthesis of thiazole aminophosphine oxides, aminophosphonic and aminophosphinic acids and $\mathrm{Cu}(\mathrm{II})$ binding abilities of thiazole aminophosphonic acids. Tetrahedron 62:2183-2189

22. Pichierri P, Sarai A (1999) Properties of phosphorothioate DNA analogs. An ab initio study of prototype model linkages derived from dimethyl-phosphate anion. J Mol Struct: Theochem 460:103-116

23. Bertrand HO, Pullman A, Zakrzewska K, Hartmann B, Fermandjian S (1999) Determination of a set of parameters for the molecular modelling of phosphorothioate DNA. Theor Chem Acc 101:269-273

24. Swierczek K, Pandey AS, Peters JW, Hengge AC (2003) A comparison of phosphonothioic acids with phosphonic acids as phosphatase inhibitors. J Med Chem 46:3703-3708

25. Volk DE, Power TD, Gorenstein DG, Luxon BA (2002) An ab initio study of phosphorothioate and phosphorodithioate interactions with sodium cation. Tetrahedron Lett 43:4443-4447

26. Liu Y, Gregersen BA, Lopez X, York DM (2005) Density functional study of the in-line mechanism of methanolysis of cyclic phosphate and thiophosphate esters in solution: insight into thio effects in RNA transesterification. J Phys Chem B 109:19987-20003

27. Becke AD (1993) Density-functional thermochemistry. III. The role of exact exchange. J Chem Phys 98:5648-5652

28. Lee C, Yang W, Parr RG (1988) Development of the ColleSalvetti correlation-energy formula into a functional of the electron density. Phys Rev B 37:785-789

29. Peng C, Ayala PY, Schlegel HB, Frisch MJ (1996) Using redundant internal coordinates to optimize equilibrium geometries and transition states. J Comput Chem 17:49-56

30. Frisch MJ, Trucks GW, Schlegel HB, Scuseria GE, Robb MA, Cheeseman JR, Montgomery JA, Jr., Vreven T, Kudin KN, Burant JC, Millam JM, Iyengar SS, Tomasi J, Barone V, Mennucci B, Cossi M, Scalmani G, Rega N, Petersson GA, Nakatsuji H, Hada M, Ehara M, Toyota K, Fukuda R, Hasegawa J, Ishida M, Nakajima T, Honda Y, Kitao O, Nakai H, Klene M, Li X, Knox JE, Hratchian HP, Cross JB, Bakken V, Adamo C, Jaramillo J, Gomperts R, Stratmann RE, Yazyev O, Austin AJ, Cammi R,
Pomelli C, Ochterski JW, Ayala PY, Morokuma K, Voth GA, Salvador P, Dannenberg JJ, Zakrzewski VG, Dapprich S, Daniels AD, Strain MC, Farkas O, Malick DK, Rabuck AD, Raghavachari $\mathrm{K}$, Foresman JB, Ortiz JV, Cui Q, Baboul AG, Clifford S, Cioslowski J, Stefanov BB, Liu G, Liashenko A, Piskorz P, Komaromi I, Martin RL, Fox DJ, Keith T, Al-Laham MA, Peng CY, Nanayakkara A, Challacombe M, Gill PMW, Johnson B, Chen W, Wong MW, Gonzalez C, Pople JA. Gaussian 03, Rev. D.1. [Revision C.02]. 2004. Wallingford, CT, Gaussian, Inc

31. Foresman JB, Frisch E (1996) Exploring chemistry with electronic structure methods. Gaussian, Inc., Pittsburgh, PA

32. Cohen AJ, Mori-Sanchez P, Yang W (2008) Insights into current limitations of density functional theory. Science 321:792-794

33. Lewars E (2003) Computational chemistry. Kluwer Academic Publishers, Dordrecht

34. Reed AE, Curtiss LA, Weinhold F (1988) Intermolecular interactions from a natural bond orbital, donor-acceptor viewpoint. Chem Rev 88:899-926

35. Barone V, Cossi M (1998) Quantum calculation of molecular energies and energy gradients in solution by a conductor solvent model. J Phys Chem A 102:1995-2001

36. Corbridge DEC (1985) Studies in inorganic chemistry 6, phosphorus. Elsevier, Amsterdam

37. Ruben EA, Plumley JA, Chapman MS, Evanseck JD (2008) Anomeric effect in "high energy" phosphate bonds, selective destabilization of the scissile bond and modulation of the exothermicity of hydrolysis. J Am Chem Soc 130:3349-3358

38. Liang C, Allen LC (1987) Sulfur does not form double bonds in phosphorothioate anions. J Am Chem Soc 109:6449-6453

39. Duncan IA, Glidewell C (1975) Ambident nucleophiles: I. Reaction of sodium diisopropylphosphorothioate with some halides of group IV. J Organomet Chem 97:51-58

40. Hahn J, Nataniel T (1987) Schwefel-Phosphor Heterocyclen RP (S)Sn, Darstellung, Struktur und Eigenschaften. Z Anorg Allg Chem 548:180-192

41. Hahn J, Nataniel T (1986) Trimethylsilyl- und Trimethylstannylester der Trithiophosphonsäuren; Darstellung, Protolyse und weitere Reaktionen. Z Anorg Allg Chem 543:7-21

42. Nizamov IS, Popovich AE, Batyeva ES, Alfonsov VA (2000) New methods of syntheses of silyl derivatives of phosphorus(V) thioacids on the basis of tetraphosphorus decasulfide, 1, 3, 2, 4-dithiadiphosphetane-2, 4-disulfides, and bis(trimethylsilyl)acetamide. Heteroat Chem 11:276-280

43. Nizamov IS, Sergeenko GG, Nizamov ID, Popovich YE, Khaibullin RN, Al'metkina LA, Abalonin BE, Batyeva ES, Krivolapov DB, Litvinov IA (2004) Disilyl dithiophosphonates in the synthesis of open chain and cyclic organothiophosphorus compounds. Heteroat Chem 15:225-232

44. Chojnowski J, Cypryk M, Michalski J, Woźniak L (1985) The nature and consequences of the interaction of phosphoryl nucleophiles with a triorganosilyl chloride. J Organomet Chem 288:275-282

45. Woźniak L, Cypryk M, Chojnowski J, Lanneau G (1989) Optically active silyl esters of phosphorus. II. Stereochemistry of reactions with nucleophiles. Tetrahedron 45:4403-4414 